MedieKultur | Journal of media and communication research | ISSN 1901-9726

Article - Open section

\title{
Hvorfor og hvordan 'betyder' nethandel? Om blandingen af teksttyper i Zalandos netbutik
}

\section{Thomas Hestbæk Andersen og Theo van Leeuwen}

MedieKultur 2018, 138-164

Published by SMID | Society of Media researchers In Denmark | www.smid.dk

The online version of this text can be found open access at https://tidsskrift.dk/mediekultur

\begin{abstract}
Shopping is one of the many everyday activities that are increasingly digitally remediated. This not only transforms the high streets of our villages and towns, but also the way customers and retailers interact, the way retailers present goods to customers, the way customers can examine goods, and the perceived and real risks customers are exposed to. Goods that can be touched and handled in markets and brick-\&-mortar shops must now be inspected and selected by means of words and images, which presupposes linguistic and visual literacies. This article centres on an analysis of Zalando's use of multimodal resources, and it shows how different registers intertwine. Also, it points to an increasing importance of language and it suggests that online shopping may in fact be less multimodal than face to face shopping, requiring linguistic skills and literacies not everyone possesses. The text analysis is related to findings from eye-tracking research and to findings from marketing studies, and thus bridges between different approaches to the study of online shopping.
\end{abstract}


Article: Hvorfor og hvordan 'betyder' nethandel?

\section{Indledning}

I denne artikel analyserer vi de betydninger, som er i spil på websiden www.zalando. co.uk, og relaterer disse til den situation, som websiden fungerer i. Denne analyse er interessant, fordi vi lever i en tid, hvor digitalisering ændrer en lang række menneskelige interaktionsmønstre (jf. Johannesen \& Boeriis, forthc.; Lemke, 2009) i en udstrækning, der har ført til idéen om 'the digital turn' (Westera, 2013). Således har det sidste tiår set en konstant mere omsiggribende udvikling væk fra fysiske real-life til virtuelle, digitaliserede udvekslinger af betydning, og denne digitale (re)mediering gør sig ikke mindst gældende inden for køb og salg af ting og serviceydelser, altså inden for nethandel. Handel faciliteres i stigende grad af internettet (se fx DIBS' årlige rapporter om "Dansk Nethandel"), hvilket ændrer denne sociale praksis på en række områder - fx måden at kommunikere på mellem sælger og kunde (jf. Endo et al., 2012), måden, hvorpå kunden præsenteres for varer (jf. Schramm-Klein et al., 2007), måden, hvorpå kunden er begrænset i sin undersøgelse af de tilbudte varer (jf. Blazquez, 2014), og måden, hvorpå kunden opfatter risici forbundet med at gennemføre et køb (jf. Aghekyan-Simonian et al., 2012; Kim \& Forsythe, 2009; Azar et al., 2015).

I forbindelse med digitaliseringen af handel med ting og serviceydelser sker der en art remediering (jf. Bolter \& Grusin, 2000) af de teksttyper, vi kender, fx produktark og katalog. Snarere end at være optagede af remedieringen fra én type tekst til en anden fokuserer vi i denne artikel imidlertid på skiftet fra en fysisk, materiel social praksis (jf. van Leeuwen, 2008) til semiotisk tekst, altså på den internetbaserede tekstliggørelse af den fysiske, materielle virkelighed. På den vis er vores fokus ikke remediering, men 'resemiotisering' (jf. ledema, 2001, 2003). Som et led i vores forskning i digitaliseringens resemiotiserende konsekvenser bidrager denne artikel især med en forståelse af, hvilke betydninger der er i spil i forbindelse med internethandel. Idet vi ønsker at anskueliggøre skiftet i selve den sociale praksis (fra det fysiske, materielle til det digitale, internetbaserede), analyserer vi med data fra et eyetracking-eksperiment ikke kun betydningerne, men også, hvordan brugere interagerer med de betydninger, som stilles til rådighed på en webside. Endelig ønsker vi at forstå, hvorfor mennesker interagerer, som de gør, og dette aspekt undersøger vi dels gennem opfølgende interviews til eyetracking-eksperimentet, dels med en læsning af marketinglitteraturens behaviorale tradition (jf. Blazquez, 2014; Cummins et al., 2014), især den del, som beskæftiger sig med online marketing og handel. Artiklen besvarer således forskningsspørgsmålene (i) Hvilke betydninger er til rådighed for brugerne af websiden zalando.co.uk, og (ii) Hvordan interagerer brugerne med af de forhåndenvarende betydninger, og hvorfor?

I det følgende præsenterer vi i afsnit 2 først den metodiske ramme for artiklens analyser og undersøgelser, herunder de data, som vi analyserer. Dernæst følger afsnit 3 med artiklens teoretiske og medievidenskabelige forankring, hvor vi både opridser det teoretiske fundament for artiklens analyser, herunder fastlægger en række nøglebegreber, og positionerer vores teoretiske ståsted inden for medieforskningen. Afsnit 4 rummer 
analysen af Zalandos webside (jf. forskningsspørgsmål (i)) og følges af afsnit 5, hvori vi adresserer forskningsspørgsmål (ii), altså brugen af Zalandos webside og motiver bag denne brug. Afsnit 6 er artiklens konklusion.

\section{Metode og data}

I forlængelse af forskningsspørgsmålene bevæger vi os i artiklens analyser fra tekst til kontekst (jf. Halliday, 1978), eller med andre, beslægtede begreber: fra mikroniveau til makroniveau (jf. Heaney, 2013, p. 165), fra semiotisk artefakt til artefakten i brug (jf. Björkvalls konceptualisering af den "sociosemiotiska etnografin"; Björkvall, 2012) eller indefra og ud (jf. Fairclough, 1992). Vi præsenterer altså et eksplorativt tekststudie, hvor tekstanalytiske observationer forklares med kontekstualiserende studier: Vi går således induktivt til værks og spørger først hvad møder vi i teksten?, hvorefter vi knytter an til (især) samfundsvidenskabelige populationsstudier inden for marketing i en søgen efter svaret på spørgsmålet - og hvorfor møder vi så det, vi gør?

Mere konkret giver vi med et (let simplificeret) sitemap et overblik over de væsentligste (under)sider på www.zalando.co.uk, og herefter analyserer vi de signifikante træk ved de teksttyper ('registre', jf. afsnit 3), som er i spil på websiden. Tekstanalysen følges op af en kontekstanalyse af kunders interaktion med websiden og deres motiver for den udviste adfærd. Kontekstanalysen af kundeadfærd baserer sig på 12 købsepisoder i Zalandos netbutik. De 12 købsepisoder er optaget med en skærmbaseret eyetracker, og efter hver købsepisode er kunderne blevet interviewet om deres oplevelse med Zalandos webunivers, herunder deres motiver for at interagere med websiden, som de gør. Denne del af interviewundersøgelsen peger frem mod inddragelsen af marketingforskningens indsigter i online marketing og handel, idet marketingforskningen netop har kunders motiver og motiverede adfærd for øje.

Hvad angår tekstanalysens data, så udgøres disse af sproglige og visuelle tekstelementer og -mønstre ("clusters", jf. Baldry \& Thibault, 2006) på Zalandos webside, idet det netop er sprog og billeder, som dominerer websidens semiosis. Zalandos webside ændrer sig jævnligt, og vores analyse er et øjebliksbillede af websiden, som den fremstod i perioden marts-juni 2016. Vi medtænker et overblik over hele websiden, men analyserer alene den sektion af Zalandos netbutik, som sælger produkter til kvinder; der er to andre sektioner, nemlig én med produkter til mænd og én med produkter til børn. Med denne opdeling mimer Zalando det klassiske stormagasin, fx Harrod's eller Magasin. De tre sektioner minder om hinanden, hvad angår tekstelementer og -mønstre, og vi betragter derfor sektionen med produkter til kvinder som karakteristisk for betydningsskabelsen $\mathrm{i}$ hele Zalandos webunivers. Denne sektion er i øvrigt langt den største.

Eyetracking-eksperimentet involverer seks forskellige kunder, som vi har bedt om at købe hhv. (i) 'et produkt til dig selv, som du kender, men som du ikke har købt online før', og (ii) 'en gave til en, du kender', dvs. i alt 12 købsepisoder. Alle seks kunder er kvinder i 
alderen 20-25 år, hvilket afspejler tekstanalysens fokus på sektionen for produkter til kvinder i Zalandos netbutik. Vores valg af sektionen for produkter til kvinder og i forlængelse heraf kvindelige analysesubjekter skyldes, at en langt større andel af kvinder end mænd nethandler 'tøj og sko' (Melsen, 2015; DE, 2016), ligesom især kvinder op til 25-års alderen nethandler inden for denne kategori; så da en selektion pga. en ellers uoverskuelig datamængde har været nødvendig, har vi valgt den største kundegruppe af det varesortiment, som Zalando udbyder. Med sit fokus på alene kvindelige kunder er vores undersøgelse selvfølgelig ikke repræsentativ for al internetbaseret handel, men det har heller ikke været et mål, idet vi ikke har ønsket at eftergøre marketinglitteraturens populationsstudier, som fungerer ud fra en kvantitativ frem for kvalitativ logik.

Eyetracking er "the process of recording the gaze of a person and the movement of the eyes from one point to another" (Saldanha \& O'Brien, 2013, p. 136), og vores formål med eyetracking-eksperimentet har været at indsamle data om interaktionen med websiden; interaktionen, altså kundens adfærd, er både øjets bevægelsesmønstre rundt på websiden som helhed og på dens forskellige undersider, ligesom eyetracking registrerer brugen af musen, altså dels hvad der klikkes på, dels hvornår der klikkes. Som et sekundært og mere generelt formål har vi med inddragelsen af eyetracking ønsket at demonstrere denne empiriske metodes brugbarhed i kombination med tekstanalyse i studiet af digitalt medieret interaktion, og bemærker i denne sammenhæng, at eyetracking gennem især det seneste årti har vundet stadig større indpas i socialsemiotiske studier (jf. Taylor, 2017; Holsanova \& Holmqvist, 2006).

Vores dataindsamling har som ovenfor nævnt yderligere involveret opfølgende interviews i forbindelse med eyetracking-eksperimentet, hvor vi har spurgt analysesubjekterne om baggrunden for deres adfærd i Zalandos digitale univers. Disse interviews kunne være næranalyseret som et selvstændigt datasæt, men her er de via en meningskondensering (jf. Kvale, 1994) alene brugt som perspektiv på de data, som eyetrackingen har registreret.

\section{Teoretisk og medievidenskabelig forankring}

Selve tekstanalysen, altså besvarelsen af forskningsspørgsmålet Hvilke betydninger er til rådighed for brugerne af websiden, foretager vi ud fra en kobling af systemisk-funktionelle indsigter i sprog (jf. Andersen \& Holsting, 2015 om dansk; se som referenceværk Halliday \& Matthiessen, 2013) og socialsemiotiske indsigter i multimodalitet og visuel kommunikation (jf. Kress \& van Leeuwen, 1996; Kress, 2010; Martinec \& van Leeuwen, 2009).

Socialsemiotikken er et sociologisk forankret (jf. Halliday, 1978, p. 38; se også Halliday \& Matthiessen, 1999, p. 2) og detaljeorienteret teorikompleks, som beskæftiger sig med en mangfoldighed af menneskelig betydningsskabelse i ord, gestik, mimik, billeder, bygninger, lyde, beklædning, etc. Alle disse typer af semiosis er organiseret i systemer af kontraster og ligheder (jf. Butt og Matthiessen, 2000), og når vi kommunikerer, aktualiserer vi på skift dele af de forskellige semiotiske systemer, som vi kender - både når vi producerer en 
tekst, og når vi forstår en tekst. Forholdet mellem systemer og tekst er illustreret nedenfor i Figur 1, hvor vi kan forestille os, at teksten er en besked sendt via det sociale medie Snapchat, og denne besked aktualiserer dele af hhv. et fotografisk system ('system a'), sproget ('system b') og et system af grafiske effekter ('system c').

Figur 1: Aktualisering af systemer i tekst

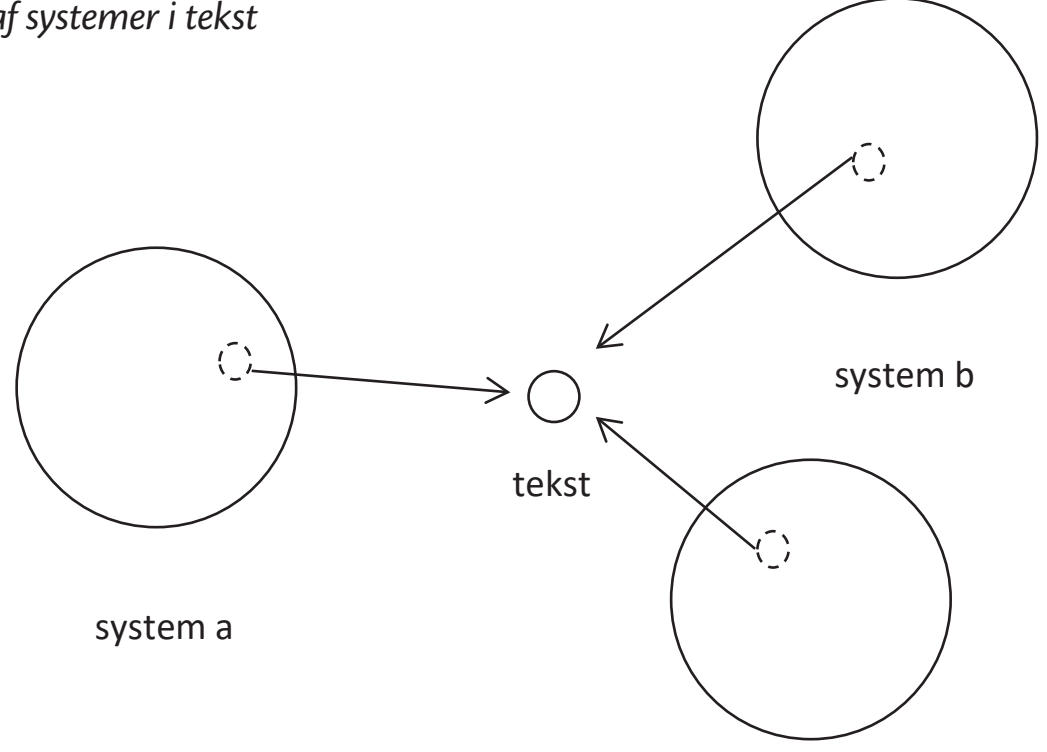

system c

I en socialsemiotisk ramme er en tekst altså en aktualisering af elementer fra et eller flere semiotiske systemer. Når elementerne aktualiseres og tager form som en tekst, opstår der med Halliday og Hasans ord en "semantic unit" (jf. 1976, p. 2). Enhver sådan enhed, altså enhver tekst, skabes som middel til interaktion (jf. Halliday, 1977, p. 51). Disse betragtninger om, hvad en tekst er, og hvordan den fungerer, gør socialsemiotikken egnet til analyse af Zalandos webside. Zalando-websidens specifikke aktualisering af (dele fra) forskellige betydningssystemer ( $\mathrm{f} x$ valget af farvepalet og valget af generelt layout) og dens menustruktur og de mange hypertekstelementer, som alene forbinder sig til andre dele af Zalandos webside, afgrænser den fra andre websider. Websiden fremtræder altså i sin helhed som en semantisk enhed. Samtidig er zalando.co.uk som enhver webside grundlæggende organiseret som hypertekst, altså af tekstelementer, som forbinder sig ('linker') til andre tekstelementer (jf. Barnet, 2014, p. 73), og ved at klikke eller trykke konstruerer enhver bruger sin egen tekst(oplevelse) ud af disse tekstelementer: Det interaktionelle aspekt $i$ konstruktionen af en tekst er altså tydeligt.

På et specifikt plan kombineres en række tekstelementer (billeder af beklædningsgenstande, beskrivelser af beklædningsgenstande, størrelsesguides, etc.) på Zalandos webside. På et mere generaliseret plan kombinerer websiden en række distinkte 
teksttyper - eller registre. I socialsemiotikken bruges betegnelsen register i stedet for teksttype (jf. Halliday \& Matthiessen, 2013, p. 29), og et register kan kort defineres som "an integration of resources (both semantic and lexicogrammatical resources) typically associated with a certain text type" (Halliday, 1978, p. 111). Registerbegrebet er beslægtet med Firths "restricted languages", som betegner tekstvarianter, der hver har "its own grammar and dictionary" (Firth, 1957, p. 87), og som er typiske for et specifikt "field of experience and action" (ibid., p. 124; jf. Firth, 1968, p. 106). Et register minder således om sociolingvistikkens idé om stilart, hvor Holmes eksempelvis opererer med følgende stilarter:

Journalese, baby-talk, legalese, the language of auctioneers, race-callers, and sports commentators, the language of airline pilots, criminals, financiers, politicians and disc jockeys, the language of the court room and the classroom... (1992, p. 276).

Socialsemiotikken har umiddelbart sin styrke i dens teori om og detaljerede deskription af mekanismerne i en tekst og i forlængelse heraf dens registerbegreb. Den er til gengæld mindre udtømmende med hensyn til, hvad kontekst er, og hvordan studiet heraf skal gribes an (jf. Andersen, 2013, 2015). Med holistiske briller defineres kontekst som "the total environment in which a text unfolds" (Halliday \& Hasan, 1985, p. 5). Denne definition er problematisk, idet den intet afgrænser, men baserer sig på en holistisk tese om, at alt hænger sammen. Definitionen bliver således temmelig uanvendelig at operere med.

Problemet med en uhåndterbar kontekst adresseres inden for socialsemiotikken ved, at der skelnes mellem kulturel kontekst og situationskontekst. Den kulturelle kontekst forbliver uhåndterbar (som "the total environment..."), mens situationskonteksten konkretiseres til tre faktorer: "Tenor" fokuserer på, hvordan teksten muliggør og begrænser relationen mellem de interagerende parter, "field" fokuserer på, hvilken social proces ( $f x$ udvekslingen af varer) det handler om, mens "mode" fokuserer på tekstens rolle som medium (jf. Halliday, 1977, p. 55). Vi fokuserer særligt på "field", herunder især de motiver, som kunden bærer med sig ind i den situation, hvor hun begynder at interagere med Zalandos webside. I vores kvalificering af forståelsen af konteksten omkring Zalandos webside knytter vi an til indsigter fra marketinglitteraturens behandling af emnet. Samfundsvidenskabelige marketingstudier fokuserer ikke på teksten og dens funktion i forbindelse med nethandel, men netop på kundernes motiver (jf. Blazquez, 2014), herunder på deres opfattelse af risici forbundet med nethandel (jf. Aghekyan-Simonian et al., 2012; Blazquez, 2014; Azar et al., 2015; Kim \& Forsythe, 2009; Endo et al., 2012).

Med sin teoretiske forankring i socialsemiotikken og sit merkantile genstandsfelt $\mathrm{i}$ nethandel placerer artiklen sig lidt atypisk inden for medievidenskaben.

Socialsemiotikken har ikke fundet stærkt fodfæste i medieforskningen, men bidrager dog med mindre studier: Heaneys studie af de engelske dagblades behandling af den tidligere landstræner for det engelske fodboldlandshold, Fabio Capello, i nærværende tidsskrift er et sådan bidrag (Heaney, 2013), og Zappavigna \& Zhaos nylige artikel om selfien i 
New Media \& Society er et andet (2017). Heaney rammesætter sin brug af socialsemotikken i en Critical Discourse Analysis (CDA), hvorved hans artikel illustrerer, hvordan socialsemiotikken typisk anvendes i medieforskningen, nemlig som led i en CDA(-inspireret) tilgang. Udbredelsen af CDA i medievidenskaben (jf. fx Berger, 2014; Jensen, 2012) viser, at socialsemiotikken - om end ad bagveje - har en plads i dette forskningsfelt, idet CDA trækker på Hallidays socialsemiotik (jf. Fairclough, 1992).

Til trods for, at vi kan forfægte et slægtskab til CDA-traditionen (både med brugen af socialsemiotikken og med koblingen af denne med tværfaglige indsigter fra samfundsvidenskabelig forskning), er denne artikels analyse ikke kritisk i CDA-forstand, fx rettet mod afdækning af hegemoni (jf. Fairclough, 1992) eller politiske diskurser (jf. Wodak, 2015). Den er snarere kommercielt orienteret, idet den angår handel med varer og serviceydelser. Også dette positionerer artiklen lidt atypisk inden for medievidenskaben. Trods den stigende digitale (re)mediering af handel er emnet kun ganske sparsomt udforsket i medieforskningen, og det er typisk ikke merkantile områder, som medieforskningen har fokuseret på, når den har undersøgt digitalisering (jf. fx Sandviks special issue af MedieKultur (2009)). Rocamora (2016) er til en vis grad en undtagelse, idet hun især ud fra Hjarvards koncept om "mediatization" (jf. Hjarvard, 2013) bl.a. undersøger "the mediatization of fashion retail" (Rocamora, 2016, p. 9), men internethandel er kun ét nedslag blandt flere i hendes undersøgelse. Eskjærs artikel om "The mediatization of etical consumption" (2013) i dette tidsskrift skal imidlertid bemærkes som en mere markant undtagelse. Med ham - og Hjarvard (2008) samt Schultz (2004) - er det muligt at betragte denne artikels studie af nethandel som et bidrag til forståelsen af den medialisering, nethandel inkarnerer. Eskjær bemærker, hvordan "e-commerce has begun to change the face of the traditional (European) city" (2013, p. 33), hvilket vi kan betragte som den mest radikale form for medialisering, nemlig substitution (ibid.; jf. Schultz, 2004, p. 88).

\section{Analyse af www.zalando.co.uk}

I dette afsnit besvarer vi spørgsmålet: Hvilke betydninger er til rådighed for brugerne af websiden?

\section{Hvad rummer www.zalando.co.uk?}

Zalandos webside rummer en række undersider med en række semiotiske elementer, som læseren sammensætter til sin egen aktuelle tekst. Nedenstående (reducerede) sitemap giver et overblik over de væsentligste undersider på Zalandos webside: 
Figur 2: Sitemap (reduceret)

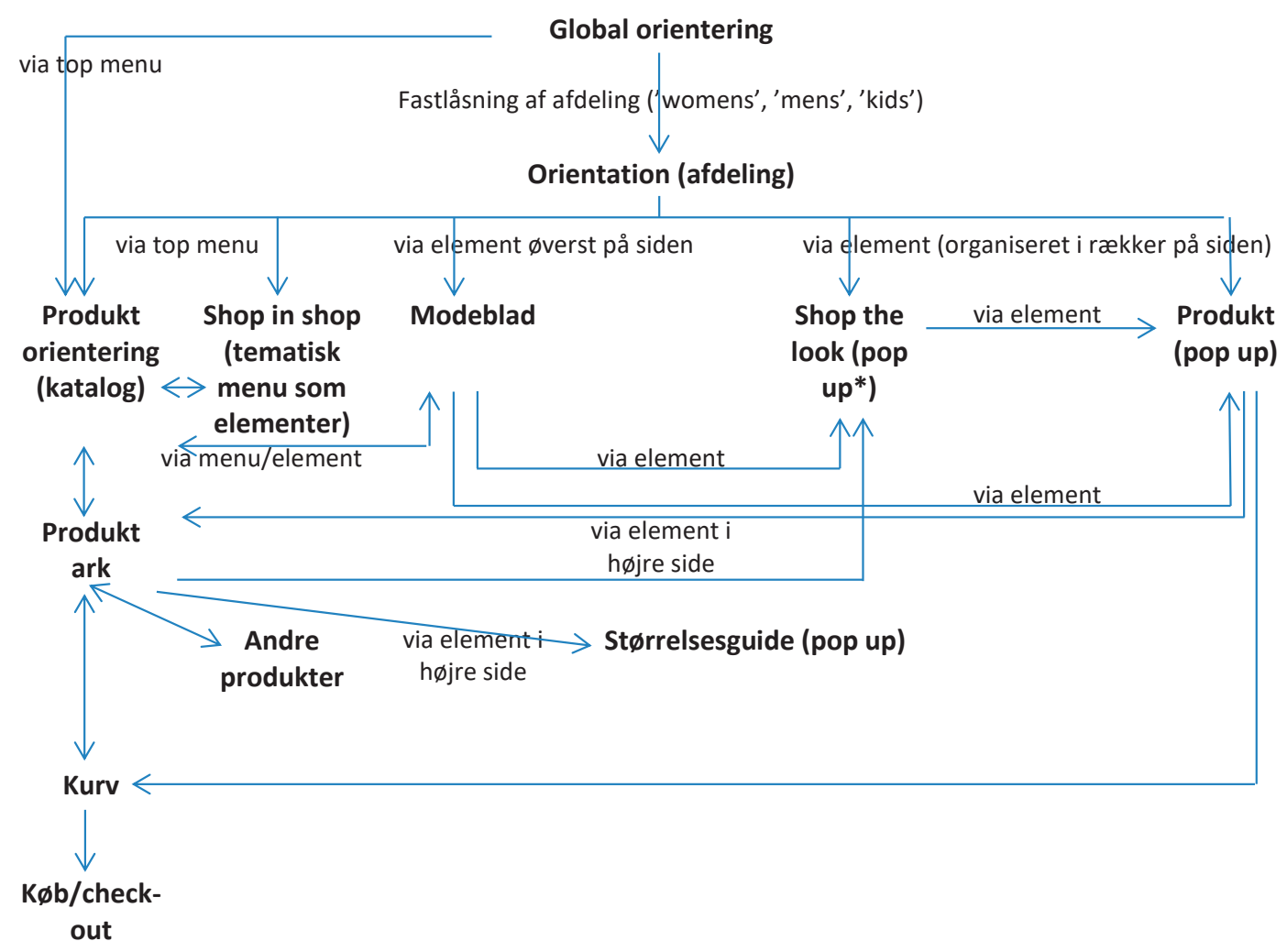

\section{Hvilke registre er i spil?}

En tekstanalyse af de forskellige undersider viser, at Zalando trækker på fem distinkte registre i sit webunivers, nemlig

(i) Et katalogregister, som aktualiseres på deciderede katalogsider.

(ii) Et produktarksregister, som anvendes på sider for de enkelte produkter.

(iii) Et handelsregister, som vi primært finder på websidens forside, på katalogsiderne og i 'check-ud'-fasen.

(iv) Et reklameregister, som især er i spil i beskrivelser af produktkategorier, fx på katalogsiderne; reklameregistret er endvidere tydeligt på forsiden.

(v) Et modebladsregister, som træder frem på katalogsiderne og i dedikerede undersider layoutet som modeblade, men også i den overordnede menu.

De tre første registre er de mest centrale, idet disse er nødvendige for, at websiden fungerer som en butik - altså for, at websiden kan opfylde sit kommercielle formål.

Kataloget er en tekst, hvis formål er at give kunden et overblik over de mange tilgængelige produkter, måske endda imponere hende med, hvor velassorteret butikken er. Katalogregistret er kendetegnet ved en fast matrixstruktur, som organiserer alt fra menuer og undermenuer ( $\mathrm{i}$ toppen og i venstre side) over søgefelt til produktbilleder $\mathrm{i}$ 
faste positioner på websiden. Kataloget består hovedsageligt af hundredvis af billeder af produkter og tilhørende ensartede captions, som er arrangeret i rækker af tre; der er således ingen fremhæuning af et produkt frem for et andet.

Billederne i kataloget viser enten produktet alene i 'full shot' og fotograferet forfra mod en neutral baggrund eller produktet på en model, hvor billedet er beskåret på en måde, så hele produktet (men ikke nødvendigvis hele modellen) er vist. Denne dekontekstualiserede (jf. Kress \& van Leeuwen, 1996, p. 170) fremstilling af tøj (på modeller) kontrasteres af mode(blads)fotografiet. Billederne er med Kress \& van Leeuwens termer analytiske (jf. 1996, pp. 89-99), idet formålet med dem er at repræsentere specifikke beklædningsgenstande tydeligt og med så stor detaljerigdom som muligt. Den analytiske funktion understreges af, at billederne forstørres, når man som kunde bevæger musen henover dem, hvorved yderligere detaljer ( $\mathrm{fx}$ syninger eller knapper eller stoffets struktur) træder frem. Således har katalogets billeder primært en repræsenterende funktion, omend der er modtagerinddragende betydninger i spil (ibid., 1996, p. 119) i de tilfælde, hvor modellen viser sit ansigt og direkte kigger på og smiler til kunden. De captions, som komplementerer billederne, angiver mærke ( $\mathrm{fx}$ 'Lauren Ralph Lauren Women'), produktnavn ( $f x^{\prime}$ BENNY'), produktkategori ( $f x$ 'blouse') og farve ( $f x^{\prime}$ black').

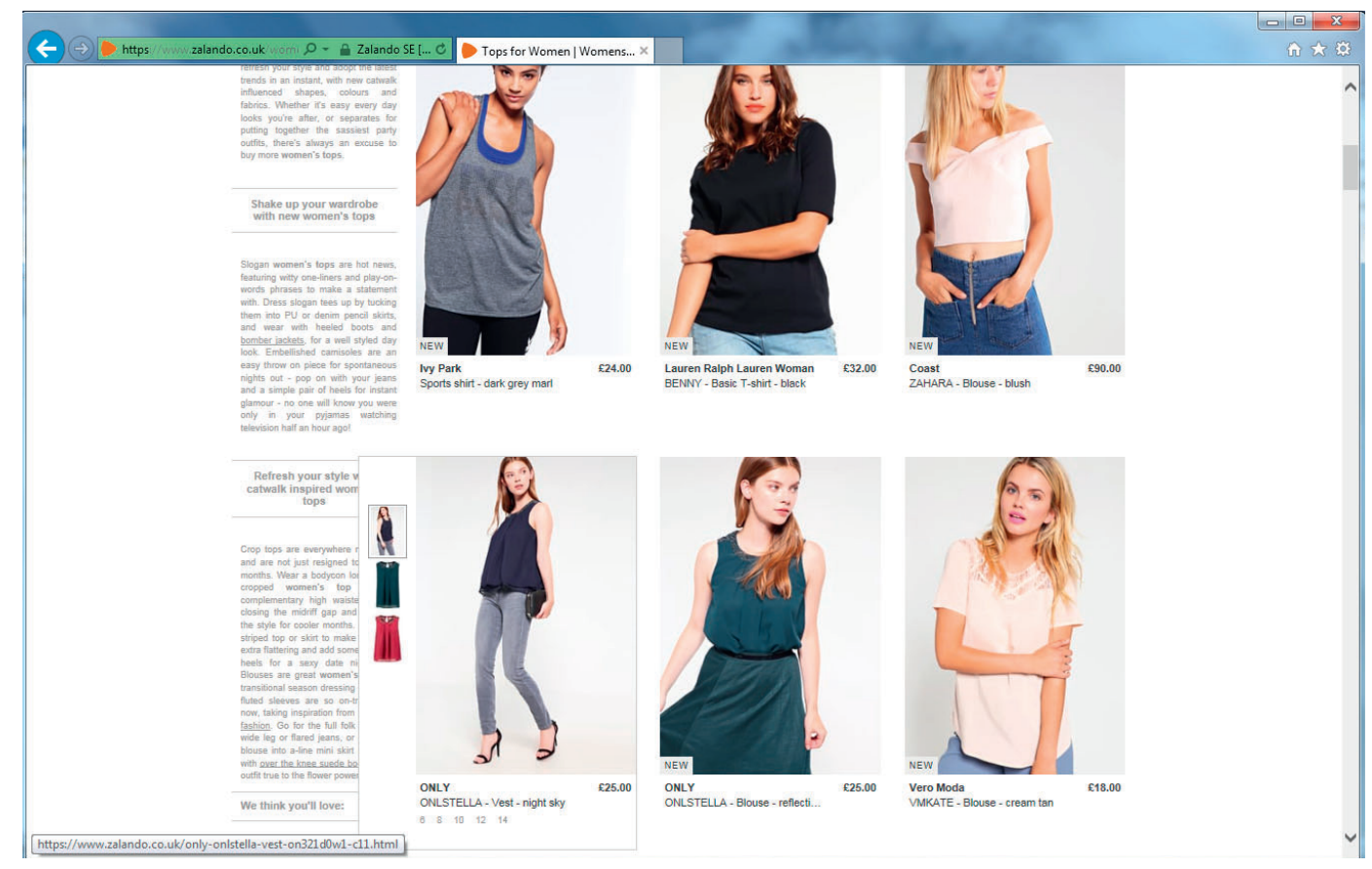

Figur 3: Screenshot af katalog

I venstre side af kataloget er der en introduktion til den produktkategori, som katalogets billeder repræsenterer. Denne introduktion er mindre fremtrædende (mindre salient, jf. Kress \& van Leeuwen, 1996, p. 183) end billederne, men er i forhold til analysen af registre 
interessant, idet den blander intet mindre end tre forskellige registre, nemlig handelsregistret, reklameregistret og modebladsregistret.

Produktarket er en udbredt, traditionel (printet) teksttype, hvis formål er et præsentere et enkelt produkts funktionelle kvaliteter (frem for at vurdere det; (den positive) vurdering falder inden for reklameregistrets formål). I bund og grund er produktarket et billede af et produkt, en koncis oversigt over dets specifikationer og en vejledende pris.

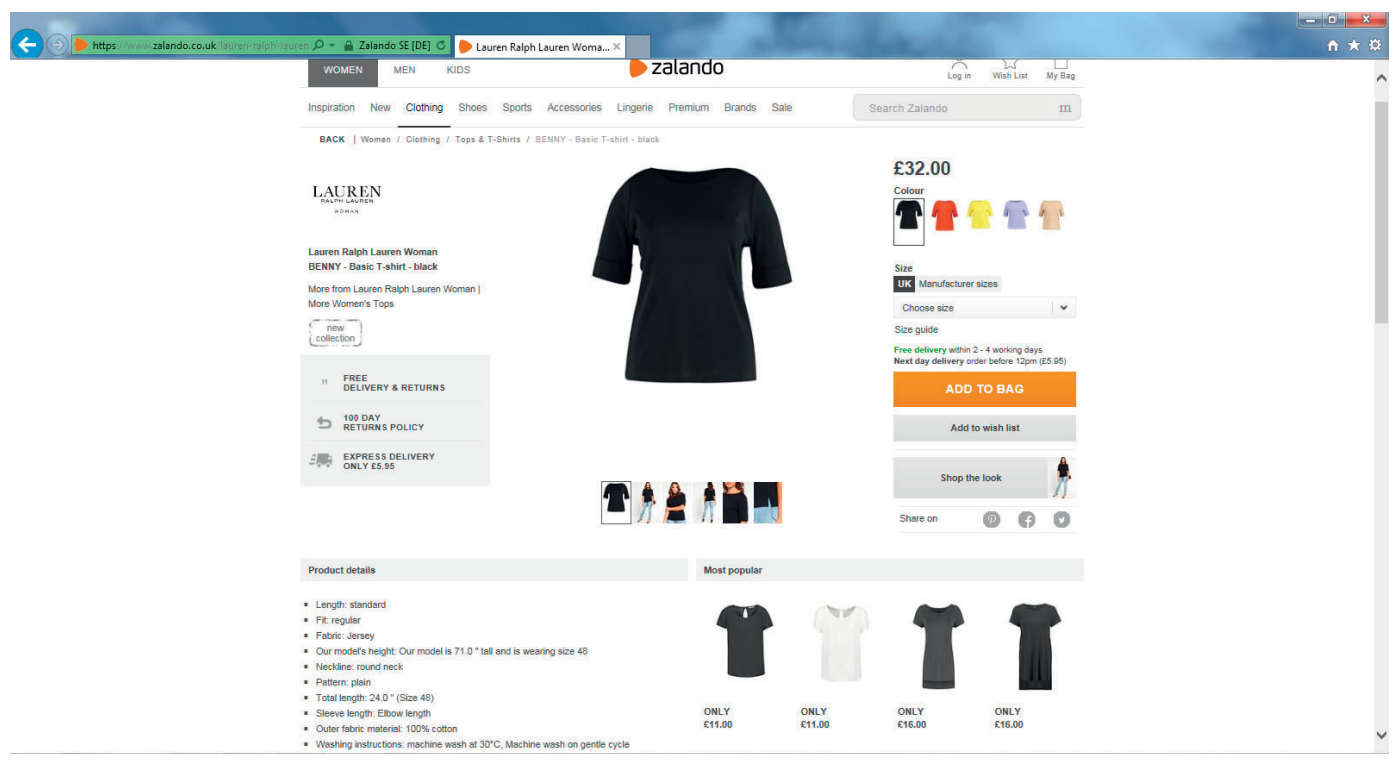

Figur 4: Screenshot af produktark

Produktarksregistret er som kataloget kendetegnet ved en matrixstruktur, som organiserer alt i faste positioner på websiden. Der er dog mere plads mellem de enkelte elementer. Det mest saliente er billedet af det dekontekstualiserede produkt i centrum, og under det er der yderligere billeder af produktet, som præsenterer det fra forskellige vinkler. På de fleste af disse billeder præsenteres produktet på en model. Til venstre for denne visuelle gengivelse af produktet findes en gentagelse af den caption, som ledsagede akkompagnerede billedet $i$ kataloget, ligesom forskellige praktikaliteter om levering og returnering angives. Til højre for produktet angives pris, og ellers præsenteres kunden her for en række mulige valg, altså handlinger, som hun kan foretage, og som vil lede frem mod et køb af produktet: Kunden kan vælge farve og størrelse på produktet, hun kan lægge det i sin indkøbskurv via det meget saliente link 'ADD TO BAG', hun kan tilføje det til sin ønskeliste (hvis hun har oprettet en sådan i Zalandos webunivers), og hun kan blive inspireret til matchende indkøb via 'Shop the look'.

På den nederste del af websiden findes en række produktdetaljer, som i punktopstilling angiver pasform, mål, størrelse, stof og vaskevejledning, samt en række yderligere 
forslag til produkter, som kunne have kundens interesse (under overskriften 'Most popular').

Handelsregistret har en række kendetegn, nemlig:

(i) Dialogiske sproglige markører i form af (a) hilsner, som fungerer hhv. salgsinitierende og -lukkende (jf. Halliday \& Hasan, 1985, p. 61) og (b) personlige pronominer i første og anden person.

(ii) Transaktionel sprogbrug i form af en række leksikalske verber, der afspejler motiver og handlinger i købssituationen; vi ser eksempler, hvor sælgeren tilbyder ('offer') et produkt, eller hvor kunden foretrækker ('prefer'), har brug for ('need'), kan finde ('look for'), kan prøve ('try') eller kan vælge ('choose') et produkt.

(iii) Angivelser af pris.

(iv) Detaljer om betaling, levering og returnering, altså beskrivelse af købsprocessen.

(v) Angivelser af størrelse, hvilket i forbindelse med køb af tøj og sko spiller en afgørende rolle.

Vi kan illustrere handelsregistrets karakteristika med følgende elementer fra Zalandos webside:

På forsiden finder vi den salgsinitierende hilsen 'WHO ARE YOU SHOPPING FOR TODAY?', som i versaler byder velkommen og samtidig leder kunden videre til et valg af den relevante afdeling: 'Women', 'Men' eller 'Kids'. Når et køb er gennemført, dvs. når betalingen er accepteret, og kunden ikke skal foretage sig mere i det digitale univers, men blot vente på leveringen af sin pakke, lukkes handlen med hilsenen 'Thank you for shopping with us! Your order has been received'.

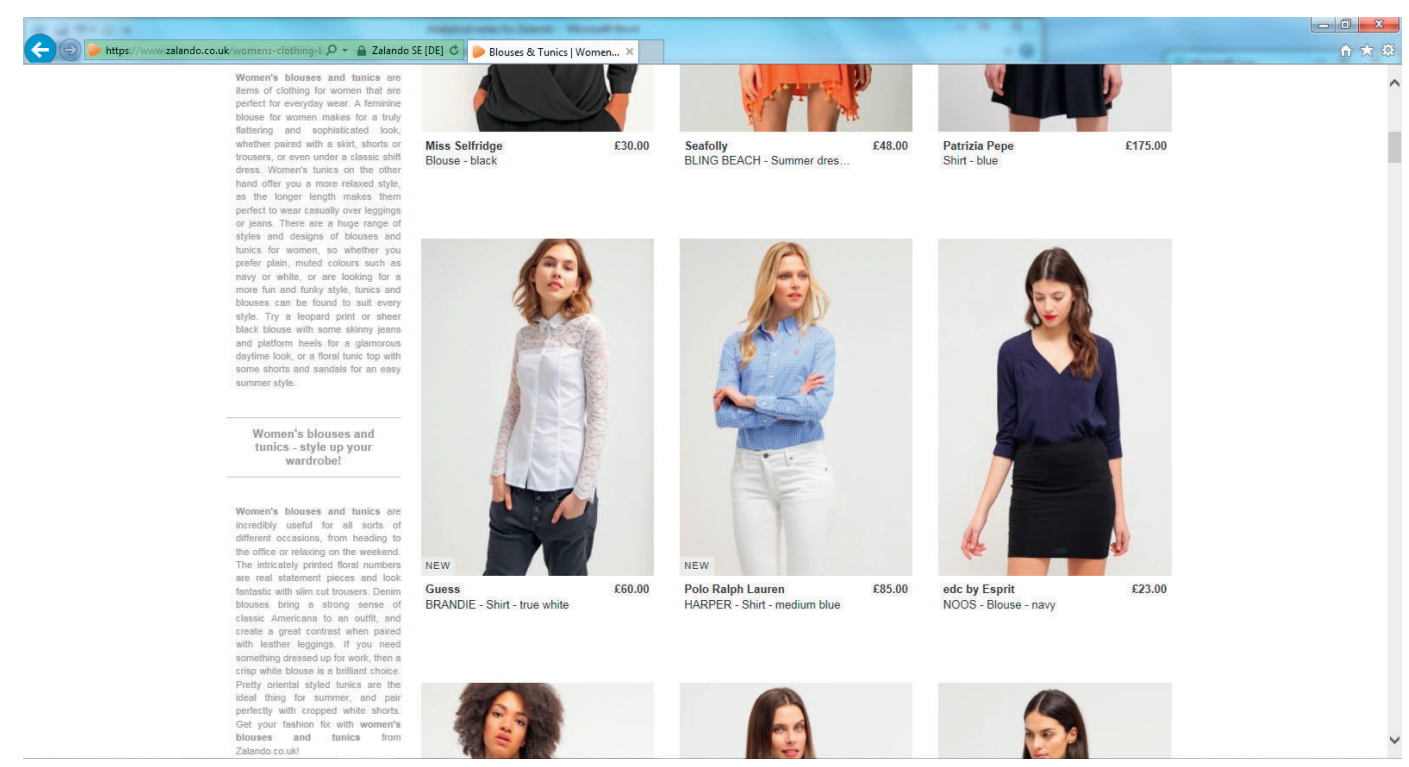

Figur 5: Screenshot af katalog for 'Women's blouses and tunics' 
Anvendelsen af personlige pronominer, den transaktionelle sprogbrug og angivelsen af pris kan illustreres ud fra kataloget for 'Women's blouses and tunics', som er gengivet i Figur 5.

I dette katalog finder vi - som i alle andre kataloger - i venstre side en introduktion til produktkategorien, og heri ser vi anvendelsen af personlige pronominer i fx den direkte modtagerinddragelse via pronominet 'you' i 'If you need something dressed up for work, then a crisp white blouse is a brilliant choice.' I den samme tekst finder vi yderligere en række eksempler på transaktionel sprogbrug, nemlig:

- 'Women's tunics on the other hand offer you a more relaxed style'

- 'whether you prefer plain, muted colours such as navy or white, or are looking for a more fun and funky style, tunics and blouses can be found to suit every style'.

- 'Try a leopard print or sheer black blouse with some skinny jeans and platform heels for a glamorous daytime look, or a floral tunic top with some shorts and sandals for an easy summer style'.

Generelt $\mathrm{i}$ katalogerne og i produktarkene er prisen på varerne saliente: I katalogerne optræder prisen selvstændigt nederst til højre under hvert billede, hvorfor det på samme tid er en del af den caption, som forankrer billedet, og får en fremhævet, lettilgængelig funktion. I produktarkene angives prisen med sidens største font.

Handelsregistret er endvidere kendetegnet ved at fortælle om detaljer vedrørende betaling, levering og returnering. Disse betydninger er meget tydelige i selve købsfasen ('check-ud'-fasen), hvilket illustreres i Figur 6 med et resultat fra eyetracking-undersøgelsen, hvor områderne 'Billing address', 'Delivery address', 'Delivery options' og 'Estimated time of delivery' er tydeligt i spil. Nedenstående eyetracking-resultat er fra trin 4 i den samlede købsfase, hvor angivelse af betalingsform er trin 3; trin 3 om betaling kan ikke gengives her, da det rummer følsomme oplysninger, men det er et trin, hvor eyetrackingen er ligeså rig som nedenfor, altså hvor der er ligeså mange øjefikseringer (angivet ved cirkler; størrelsen af en cirkel angiver den relative tid, en fiksering har varet, og tallene i cirklerne angiver rækkefølgen af øjefikseringerne) og øjebevægelser (angivet ved stregerne mellem cirklerne).

Det er ikke alene i købsfasen, at Zalando's webside tilbyder information om betaling, levering og returnering. Vi finder også undersider, som alene har til formål at fortælle om, hvor let det er at handle, og ikke mindst hvor let det er at returnere et fejkøb. Her brydes fx returneringsprocessen ned i få og håndterbare trin, som angives i en overskuelig (og kompleksitetsreducerende) punktopstilling: '1. Log into your customer account', '2. Pack the box', '3. Return it' og '4. Refund'.

Slutteligt spiller angivelse af (og valg af korrekt) størrelse en væsentlig rolle i handelsregistret. Dette tydeliggøres af, at vi i produktarkene finder en række beskrivelser af størrelse og mål, fx under 'Product details' for den t-shirt, som vi så i Figur 4 ovenfor: 'Length: standard', 'Our model's height: Our model is 71.0" tall and is wearing size 48,' 'Total length: 
Article: Hvorfor og hvordan 'betyder' nethandel?

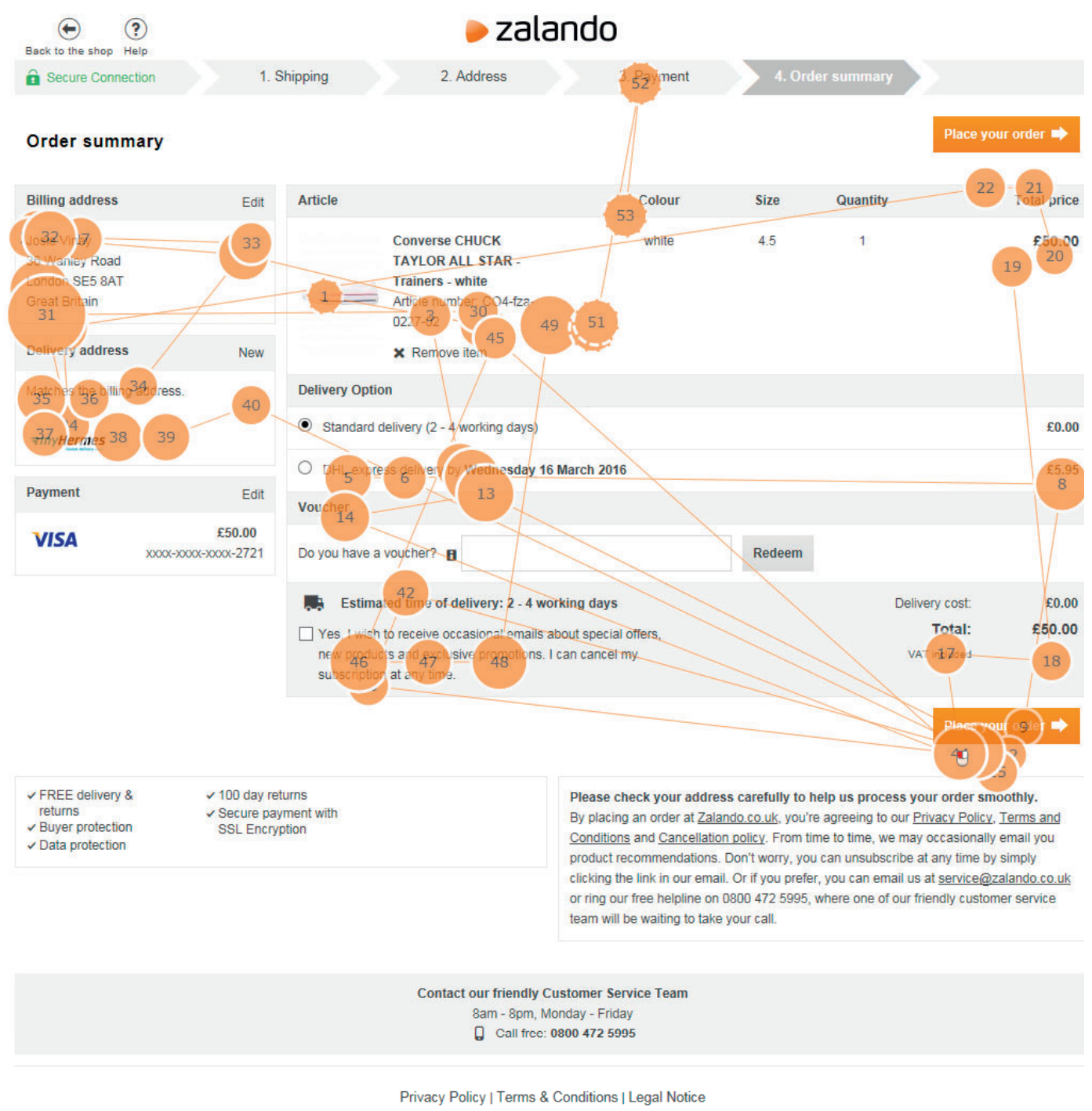

Figur 6: Eyetracking i købsfase

24.0" (size 48)', ligesom Zalando's webside i alt rummer hele ni forskellige størrelsesguider (for sko, jakkesæt, overdele, etc.), og der er adgang til en relevant størrelsesguide fra ethvert af produktarkene.

Ifølge Machin \& van Leeuwen (2007) og Andersen (2007) er reklameregistret sprogligt kendetegnet ved følgende:

(i) Modtagerinddragende ytringsfunktioner (jf. Andersen \& Holsting, 2015, p. 209), især opfordringer realiseret af imperativsætninger; ofte er det opfordringer til at anskaffe sig et bestemt produkt.

(ii) Dialogiske sproglige markører i form af personlige pronominer i første og anden person. 
(iii) Angivelser af mærke (brand) or/eller den butik, hvorfra produktet kan anskaffes.

(iv) Positive vurderinger af produktets kvaliteter eller de værdier, som associeres med produktet; dette realiseres typisk af adjektiver.

(v) Poetisk sprogbrug (jf. Jakobson, 1960), fx stilistiske virkemidler som rim og allitterationer.

Reklameregistret kan vi (også) illustrere med introduktion til produktkategorien 'Women's blouses and tunics' (jf. Figur 5). Her finder vi et eksempel på en modtagerinddragende ytringsfunktion i opfordringen: 'Try a leopard print.... Det modtagerinddragende er også i spil i: 'Get your fashion fix with women's blouses and tunics from Zalando.co.uk!'. Denne opfordring illustrerer en del af kendetegnene ved reklameregistret, idet den ud over imperativen 'Get' rummer en dialogisk markør i det personlige pronomen 'your', angivelse af butikken med 'Zalando.co.uk' samt poetisk sprogbrug, dels med allitterationen 'fashion fix', dels med rimet 'fix' - 'tunics'. En anden allitteration finder vi i 'fun and funky', der igen er del af en positiv vurdering af produktkategorien: 'a more fun and funky style'. Andre sådanne positive vurderinger via adjektiver findes i'a glamorous daytime look' og 'an easy summer style'.

På Zalandos webside finder vi også betydninger, som hører registret for modeblade til. Dette register er beskrevet i Barthes' originale The Language of Fashion (2013), og Barthes' beskrivelse er gentaget og uddybet i Moerans antropologiske gennemgang af modeblade, eller 'glossies', som han betegner dem (jf. Moeran, 2013). Ifølge Barthes og Moeran er det sproget, som gør beklædning til mode: "the use of language more than anything else transforms clothing and dress into fashion. It's language that defines what fashion is, or is not" (Moeran, 2013, p. 132, original kursivering; jf. Barthes, 2013, p. 109). Moeran forklarer, hvordan sproget, altså teksten, repræsenterer beklædning:

[W]ritten-clothing consists of two inter-related classes of utterance. One includes all the vestimentary features (forms, fabrics, colours, and so on) that signify different kinds of clothes; the other all evaluative ('discreet', 'amusing', and so on) and circumstantial ('evening', 'weekend', 'shopping', 'party', and so forth) features that signify the kinds of lives we lead in the world. (2013, p. 132).

Det er særligt de vurderende ('evaluative') termer, som Moeran hæfter sig ved, for det er disse, som gør beklædning til mere end blot beklædning, nemlig til mode (jf. ibid, p. 133).

Mens Moeran (og Barthes) således skelner mellem kategoriske elementer ('vestimentary features'; eller med Barthes betegnelse: "vesteme" (2013, p. 47)) og vurderende elementer i beskrivelsen af mode(tøj), foreslår vi en yderligere inddeling af de vurderende elementer ud fra deres betydning; dels kan modetøj vurderes æstetisk, altså ud fra smag (jf. (ii) nedenfor), dels kan det vurderes efter dets formål (jf. (iii) og (iv) nedenfor). Modetøj kan på denne vis beskrives ud fra kategoriske elementer, fx typen af kraven på en skjorte som i 'button down collar', ud fra en positiv vurdering af tøjets æstetiske kvaliteter, fx som 
'elegant', eller ud fra dets formål, hvor tøjet enten beskrives som passende for en bestemt situation, fx "for a lunchtime party in Deauville" (Barthes, 2013, p. 37) eller 'summer skirt', eller som en type beklædning, der har (positiv) indvirkning på kroppen, $\mathrm{fx}$ "the blouson dress hides hips and flattens the tummy" (Moeran, 2013, p. 121). Med andre ord kombinerer modebladsregistret

(i) Kategoriseringer af tøjet efter type. Sådanne kategoriseringer rummer ikke i sig selv en vurdering af tøjet.

(ii) Positive vurderinger af tøjet ud fra en æstetisk norm, altså smag.

(iii) Situerende beskrivelser (via 'Cirkumstantialer' jf. Andersen \& Holsting, 2015, pp. 166-183), som peger på den situation, hvor tøjet er passende.

(iv) Beskrivelser af det resultat, som tøjet vil have på opfattelsen af kroppen.

Vi kan illustrere disse registerkendetegn med den følgende tekst fra siden for 'Women's heels: Teksten fungerer som en introduktion til produktkategorien og er gengivet i Figur 7.

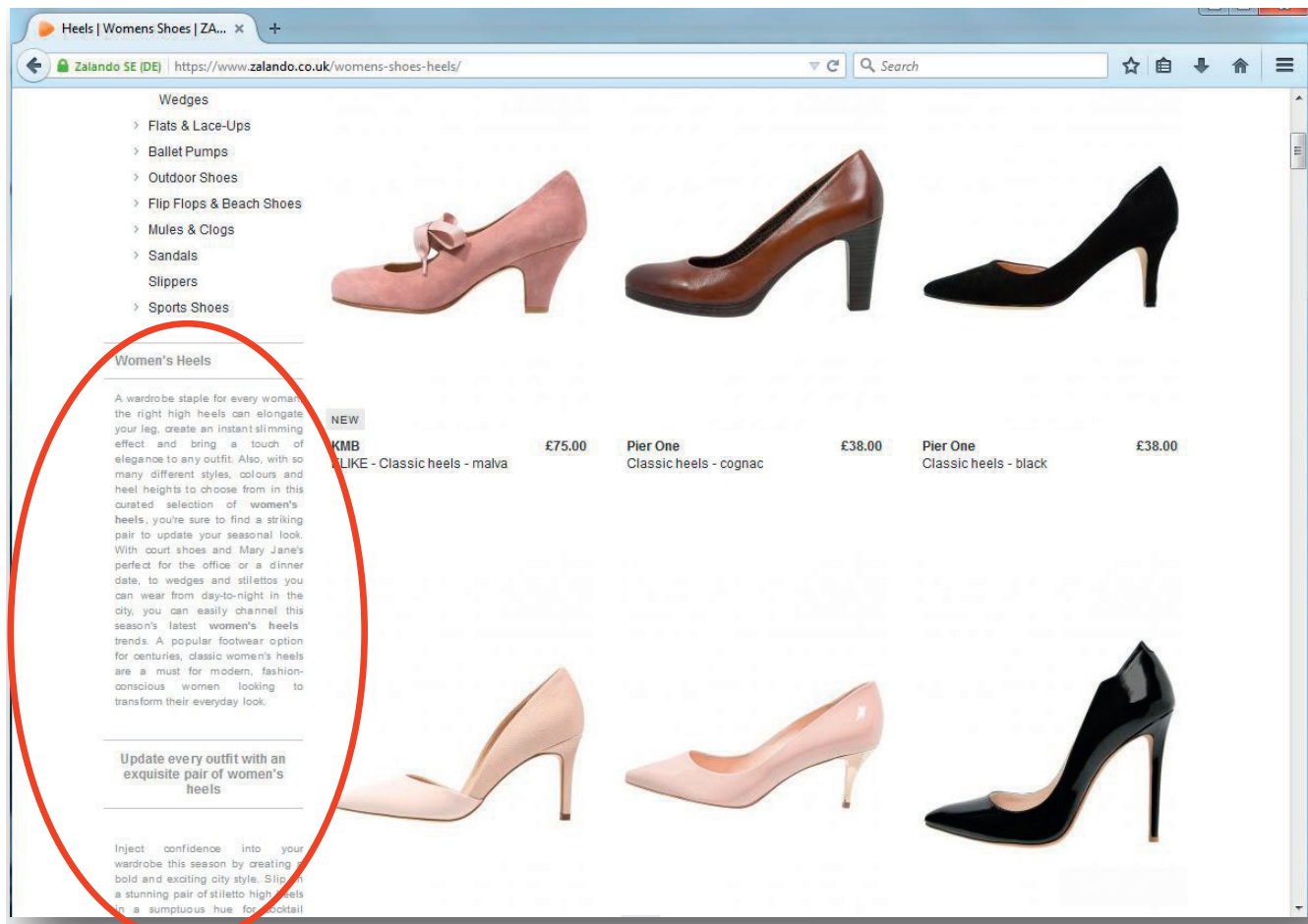

Figur 7: Screenshot af katalog for 'Women's heels'

Teksten rummer følgende kategoriseringer af tøjet efter type (vores kursivering):

- 'With court shoes and Mary Jane's perfect for the office or a dinner date, to wedges and stilettos' 
- 'Black lace-up or tan block heels'

- 'Classic kitten heels are great for everyday wear'

- 'a feminine Mary Jane style pair'

- 'Wedge heels'

- 'a fitted little black dress or structured jumpsuit'

- 'a sharp pencil skirt or tapered trousers'

- 'an on-trend pussy bow blouse'

- ' 'a retro midi bell skirt and a bejewelled top'

- 'denim shorts'.

- 'a vest top'

- 'jeans'

- 'kimono jacket'

Vi finder også en lang række eksempler på æstetisk funderede vurderinger:

- 'a striking pair'

- 'an exquisite pair of women's heels'

- 'a bold and exciting city style'

- ' 'a stunning pair of stiletto high heels in a sumptuous hue'

- 'a feminine Mary Jane style pair'

- 'a sharp pencil skirt'

- 'an on-trend pussy bow blouse'

- 'a retro midi bell skirt'

Teksten rummer følgende situerende beskrivelser:

- 'With court shoes and Mary Jane's perfect for the office or a dinner date, to wedges and stilettos you can wear from day-to-night in the city'

- 'for cocktail parties or a wedding reception'

- 'in the office'

- 'Classic kitten heels are great for everyday wear'

Og der er en enkelt beskrivelse af, hvad højhælede sko gør ved opfattelsen af kroppen i 'the right high heels can elongate your leg, create an instant slimming effect'.

Et femte kendetegn ved modebladsregistret er "the authoritative wording of someone who knows everything that is behind the confused, or incomplete appearance of the visible forms" (Barthes, 2013, pp. 108-109, original kursivering; jf. Machin \& van Leeuwen, 2007, pp. 144-145). Dette ser vi også i Zalandos introduktion til højhælede sko, idet denne ingen modalitet rummer, dvs. ikke fremstiller informationen som noget, der er til forhandling (jf. Halliday \& Matthiessen, 2013, p. 179), men i stedet rummer (selv)sikre udsagn som 'Black lace-up or tan block heels are perfect for making a fashion statement in the office'. 
Et sjette og et syvende kendetegn ved modebladsregistret er leksik, som refererer hhv. til modens grundlæggende visuelle natur (med udtryk som "the look", "the style") og til de enkelte modetendensers flygtige natur ( $\mathrm{fx}$ "this season's must have"). Disse kendetegn er kursiverede i nedenstående gentagelse af den første halvdel af teksten om 'Women's heels':

A wardrobe staple for every woman, the right high heels can elongate your leg, create an instant slimming effect and bring a touch of elegance to any outfit. Also, with so many different styles, colours and heel heights to choose from in this curated selection of women's heels, you're sure to find a striking pair to update your seasonal look. With court shoes and Mary Jane's perfect for the office or a dinner date, to wedges and stilettos you can wear from day-to-night in the city, you can easily channel this season's latest women's heels trends. A popular footwear option for centuries, classic women's heels are a must for modern, fashion-conscious women looking to transform their everyday look.

Vi ser også denne type leksik i menuen, som er fremhævet i Figur 8.

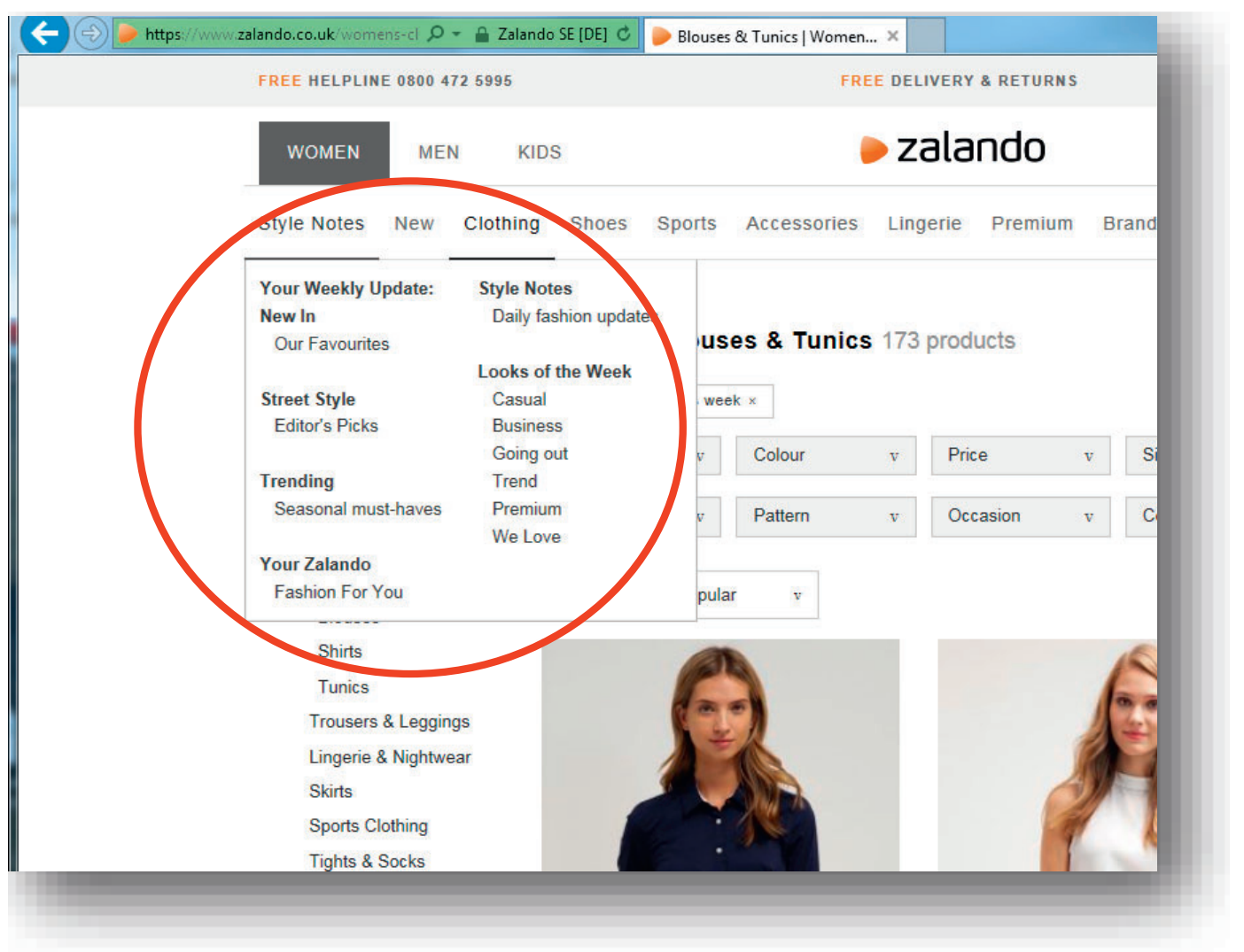

Figur 8: Screenshot af menuen 'Style Notes' 
I Zalandos butik støder vi ikke kun på modebladsregistret $\mathrm{i}$ katalogets introduktioner til en produktkategori, men også på særlige 'modebladssider', som mere omfattende mimer modeblade. Sådanne sider har til formål at fremhæve et eller andet tema, fx via den feature-artikel om den personlige træner og blogger Carla Rowena, som er gengivet i Figur 9.

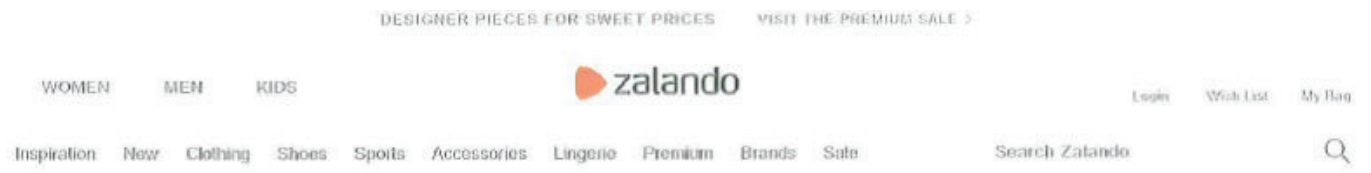

Summer is finally here and this season an active lifestyle is an absolute must. We inviled effervescent personal trainet and ifestyle blogger Carly Rowena to Bentin for an active break. She shared her lips and an epic playlist - to help you stay happy, healthy and on top of your game.

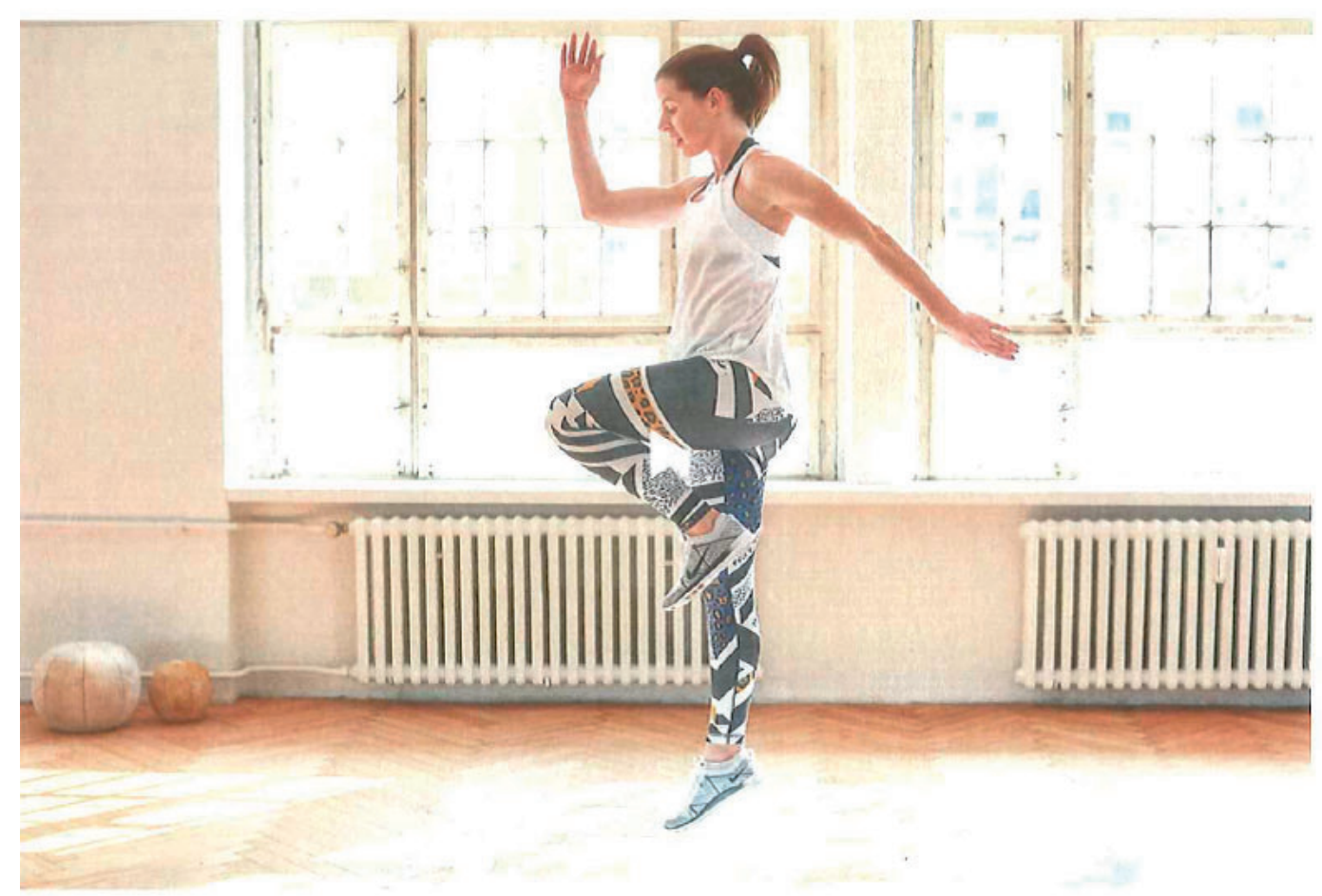

Figur 9: Screenshot af artikel om Carla Rowena

Artiklen om Carla Rowena indledes af en kort tekst efterfulgt af et billede af en trænende Carla Rowena; et billede, der fylder hele siden i bredden. Hvis vi scroller ned, finder vi et layout, som det vi kender fra modeblade: En række tekstblokke er kombineret med en 
række nogenlunde lige store billeder af Carla Rowena, der træner, laver sund mad, etc., og det hele er holdt i det samme farveskema af olivenbrune, hvide og grå nuancer.

Det kommercielle formål med sådanne modebladssider er at inspirere kunden til at købe et eller flere af de produkter, som præsenteres i sammenhæng med temaet - $\mathrm{fx}$ træningsbukser, -toppe og -sko. Ud over de forskellige tekstblokke og billeder rummer websiden derfor også links til en særlig katalogside med overskriften 'Carla's workout picks 290 products'.

\section{Hvilke betydningssystemer er de centrale?}

I ovenstående analyse af de betydninger, som Zalando tilbyder brugerne af websiden, har vi fokuseret på det sproglige og (bredt betragtet) det visuelle semiotiske system. Det har vi, fordi det er brugen af disse systemer (og ikke fx lyd eller duft eller taktilitet), som er betydningsskabende på websiden. Således viser vores studie af Zalando, at nethandel $\mathrm{i}$ mindre grad er et multimodalt fænomen, end handlen i fysiske butikker.

På Zalandos webside er det grundlæggende visuelle strukturer, som organiserer betydningen; således styres websidens betydning af en række kompositionelle forhold (jf. Kress \& van Leeuwen 1996, kap. 6), der - som ovenstående analyse demonstrerer - især angår saliens og placering efter forholdet 'centre-margin', ligesom forholdet 'given-new' spiller ind på placeringen af menupunkter i venstre side ('Given') og den ønskede handling 'Add to bag' i højre side ('New'). Trods denne overordnede komposition efter visuelle strukturer spiller sproget en væsentlig rolle på websiden. For det første fordi sproget er det semiotiske system, hvormed mode overhovedet defineres, og hvorved det (autoritativt) defineres, hvordan forskellige produkter lever op til modens tendenser og krav. For det andet fordi det er med sproget, at Zalando kan udtrykke, hvad kunden i en fysisk butik ville opfatte ved berøring, håndtering og prøvning af tøjet. Sproget er altså det væsentligste semiotiske system, når det kommer til at oversætte en række af tøjets funktionelle kvaliteter, såsom størrelse, pasform og taktilitet. Sprogliggørelsen af disse kvaliteter har den konsekvens, at brugerne af Zalandos netbutik dels skal være bekendt med et temmelig specialiseret vokabularium, dels skal have en ret præcis viden om sine egne kropsmål - eller målene på den, som man handler til.

\section{www.zalando.co.uk i brug}

I dette afsnit besvarer vi spørgsmålet: Hvordan interagerer brugerne med af de forhåndenverende betydninger, og hvorfor? Vi foretager altså et kontekstuelt udblik fra afsnit $4 \mathrm{~s}$ tekstanalyse.

\section{Hvordan bevager kunderne sig rundt på www.zalando.co.uk?}

I afsnit 4.1 gav vi et let simplificeret overblik over de væsentligste undersider på Zalandos webside. Med det som baggrund kan vi vise, hvordan vores seks kunder ( $\mathrm{i}$ 
de 12 eyetracking-forløb) bevæger sig rundt på websiden. I alle forløb er bevægelsen i overordnede træk som illustreret i nedenstående Figur 10.

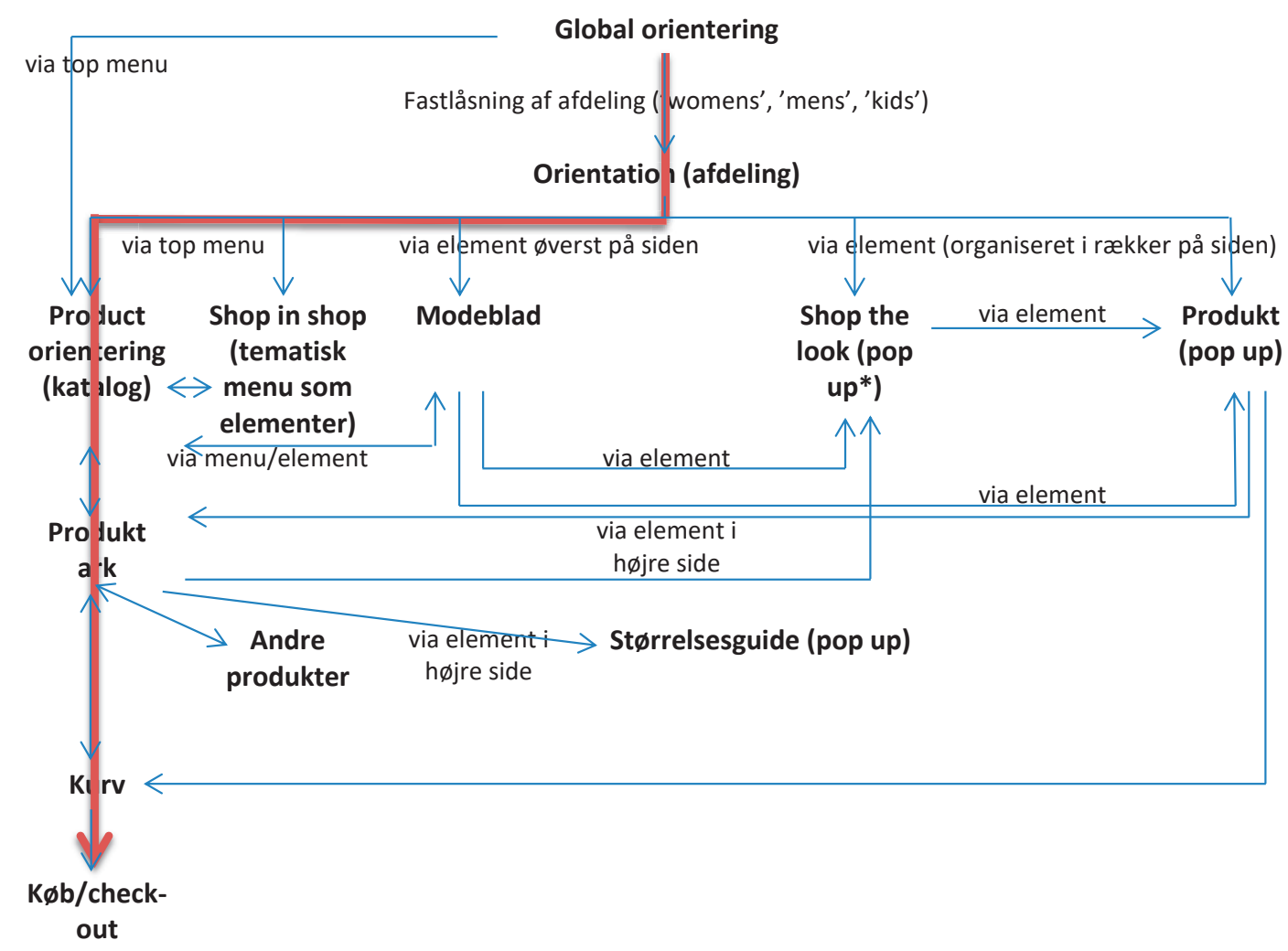

Figur 10: Bevøegelsesmønster på www.zalando.co.uk

Bevægelsesmønstret i Figur 10 repræsenterer situationen i vores eyetracking-undersøgelse, men er ikke nødvendigvis repræsentativt for alle kunders brug af Zalandos webshop; dels har vi kun haft kvindelige analysesubjekter, dels kom det i de opfølgende interviews (jf. afsnit 2) frem, at vi har baseret vores eksperiment på to forudsætninger, som ikke altid gælder: For det første, at formålet med at besøge en webshop er at foretage et køb, og for det andet, at kunden kun bevæger sig rundt på én webshop. Interviewene afslørede, at der kan være andre formål med at besøge en webshop, $\mathrm{fx}$ at blive inspireret eller holde sig orienteret om modetendenser og priser, og yderligere viste det sig, at kunder ofte besøger flere websider, $\mathrm{f} x$ forskellige webshops og sider med anmeldelser, herunder 'vagthunde' som Trustpilot, før de foretager et køb. Vores opgave, som lød 'Køb (i) et produkt til dig selv, som du kender, men som du ikke har købt online før, og (ii) en gave til en, du kender', kan, sammen med tekniske begrænsninger i eyetrackerens software, der umuliggjorde inddragelsen af mere end én webside i undersøgelse, have ensrettet trafikken, altså have registreret et for begrænset bevægelsesmønster. Yderligere er det en generel bias ved 
laboratorieforsøg, at analysesubjektet kan være påvirket af situationen og blande (opfattelsen af) forsøgets hensigter med egne motiver. $\mathrm{Vi}$ kan af den grund ikke afvise, at vores analysesubjekters adfærd har været påvirket af et ønske om simpelthen at løse de stillede opgaver; købsadfærden kan således være blevet mere opgaveorienteret og -løsende, end den ville være uden for laboratoriets kontekst.

Til trods for den ensrettende opgave er der dog variation i bevægelsesmønstret mellem de enkelte kunder, ligesom vi har observeret, at samme kunde godt kan gribe de to delopgaver forskelligt an. To bevægelsesmønstre illustrerer dette:

Kunde A klikker sig kun ganske lidt rundt på siden. Hun bevæger sig via menuen øverst på siden direkte til kataloget for den produktkategori ('Men's Jewellery'), hun ønsker at købe, hvorefter hun bruger meget lang tid på at scrolle rundt og bevæge musen over de enkelte produkter, således at billederne af disse skifter og viser forskellige detaljer og vinkler. Slutteligt vælger hun det ene produkt, som hun derefter køber. Hun læser meget lidt om produktet, men er helt overvejende orienteret mod billederne.

Kunde B bevæger sig ligeledes hurtigt til kataloget for den ønskede produktkategori ('Women's Polo Shirts'), og herefter undersøger hun metodisk ét for ét en række produkter ved at bevæge sig frem og tilbage mellem katalogside og de forskellige sider med produktark. På produktarksiderne undersøges billedet af produktet nøje ved at bevæge musen henover det, så der zoomes ind på detaljer, og de funktionelle detaljer ved produktet, altså punktopstillingen med 'Product details' (jf. Figur 4), læses indgående. Hvis et produkt synes interessant, lægges det i kurven, og sådan fortsætter hun, til hun har en række produkter i sin kurv. Her skifter bevægelsesmønstret så fra at gå mellem katalog og enkelte produktark til at gå mellem kurv og de enkelte produktark. Hun bruger altså kurven som en art ønskeliste og går herfra tilbage og kigger endnu engang på hvert af de valgte produkter, som hun så fravælger ét for ét, indtil hun kun har et enkelt tilbage. Dette køber hun så.
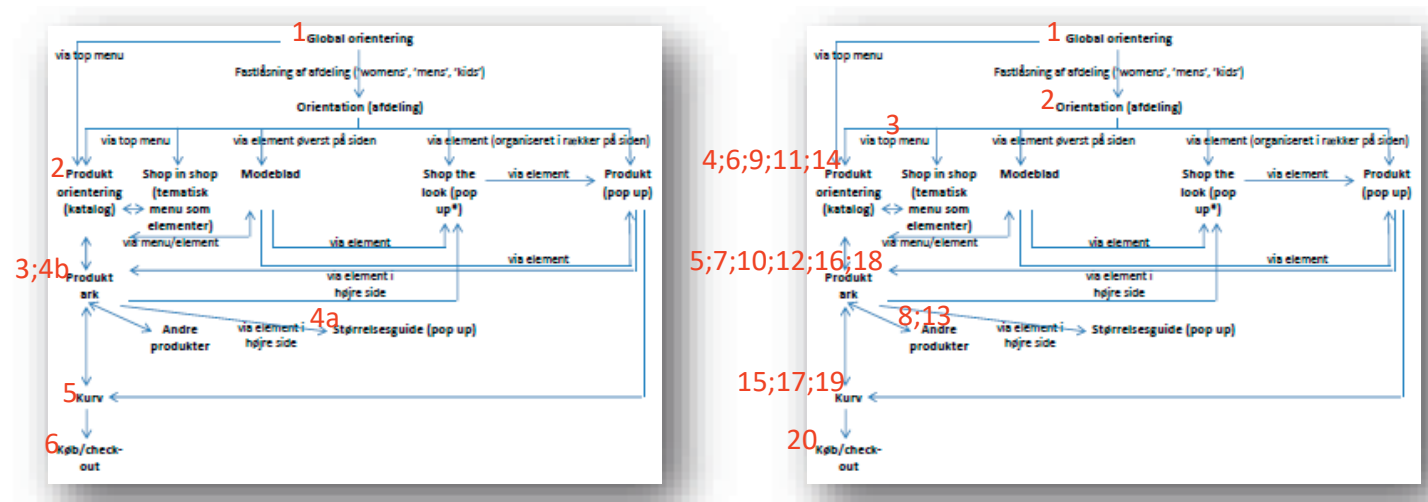

Figur 11: Bevcegelsesmønstre for hhv. kunde A og kunde B; hvert tal representerer et ophold på den pågceldende underside 


\section{Hvilke motiver har kunderne?}

Ifølge marketinglitteraturen er det afgørende for en kunde, der handler i en netbutik, at begrænse og så vidt muligt kontrollere de risici, der er forbundet hermed. Den manglende fysiske håndtering af tøjet er den største barriere i nethandel, og den giver en større følelse af risiko (Blazquez, 2014). Kim \& Forsythe (2009) og Schramm-Klein et al. (2007) understreger, at den oplevede risiko ifm. køb af tøj er særlig stor, dels fordi kunden her mangler den personlige kontakt, som kendetegner en købsoplevelse i en fysisk butik, dels fordi

many of the characteristics of apparel that are important to consumer decision making, such as fit, hand, quality and color, are difficult to present on screen and standard descriptors of a product are often insufficient for product evaluation (Kim \& Forsythe, 2009, p. 1101).

En del kunder reducerer risikoen ved at bestille det samme stykke tøj eller de samme sko i forskellige størrelser og så returnere de produkter, som ikke passer (jf. Dusto, 2012). På den måde slipper de også for at bruge tid på at afkode en størrelsesguide. Denne praksis er selvfølgelig dyr og derfor problematisk for netbutikken, og i det lys er det ikke underligt, at Zalando skriver så meget om størrelse og pasform samt tilbyder så mange størrelsesguider, som tekstanalysen viste.

I en analyse foretaget af Foreningen for Dansk Internet Handel i sensommeren 2016 pointeres det, at tidligere utilfredse kunder, manglende kontaktoplysninger samt dårlige billeder og produktbeskrivelser er de tre væsentligste årsager til, at kunder fravælger en netbutik (jf. Melander, 2016). Endo et al. (2012) og Aghekyan-Simonian et al. (2012) pointerer også de to første faktorer i deres undersøgelse af barrierer ved nethandel, men faktisk viser FDIHs analyse, at det mest problematiske er, hvis produktbeskrivelserne eller produktbillederne er for ringe: I så fald fravælger hele 81 pct. en netbutik (Melander, 2016). Et sådan analyseresultat kontekstualiserer den rigdom af (zoombare) produktbilleder, præcise captions og listede 'Product details', som tekstanalysen af Zalandos netbutik har gjort os opmærksomme på. I Zalandos tilfælde synes dårlige billeder og produktbeskrivelser således ikke være en begrundelse for fravalg.

Aghekyan-Simonian et al. inddeler oplevede risici i tre typer, nemlig (i) "product performance risk", (ii) "financial risk" og (iii) "time risk" (2012). Den første type handler om kundens opfattelse af, om produktet holder en forventet kvalitet, og her påpeges det, at det er lettere at sælge mærkevarer end produkter af ukendt oprindelse (jf. også Blazquez, 2014). Mærkevarerne betones da også i høj grad på Zalandos webside, dels $\mathrm{i}$ form i navne- og logotræk på produktark, dels i form af fremhævelse af mærket i den caption, der ledager billederne i kataloget: Her er mærket markeret med fed skrift og udgør den øverste af de to linjer i en caption. Financial risk og time risk angår især forhold ved betaling, levering og returnering, og det ukomplicerede ved sådanne transaktioner betones også af Zalando (jf. vores beskrivelse ovenfor af handelsregistret). Det 
transparente handelsforløb betones for øvrigt også af Zalando i de e-mailnotifikationer, som kunden modtager efter at have bestilt en vare: En sådan "post-purchase customer service" er ifølge Endo et al. (2012) og Azar et al. (2015) afgørende for at sikre sig et godt omdømme som netbutik.

Hvis vi betragter kundens motiver for at handle, så skelner både Kim \& Forsythe (2009) og Blazquez (2014) mellem "hedonistic motives" og "functional motives". I den gennemførte eye-tracking-undersøgelse var det funktionelle motiv tydeligt hos hovedparten af de deltagende, bl.a. hos ovennævinte kunde B, som i detaljer undersøgte de produkter, hun var interesseret i, før hun foretog et køb. Det hedonistiske motiv så vi kun udfoldet hos en enkelt, hvis fikseringer under eye-trackingen og efterfølgende interview afslørede, at hun med jævne mellemrum var mere optaget af at kigge på de (med hendes ord) "smukke modeller på billederne" end på at kigge på produktet eller læse captions. Hun var således i høj grad styret af sin æstetiske sans. Denne overvægt af adfærd baseret på et funktionelt motiv i vores eyetracking-eksperiment kunne hænge sammen med den opgave, vi stillede vores analysesubjekter: Her handlede det om at nå frem til at køb, ikke om fx at lade sig inspirere eller 'window-shoppe'. Vi kan således ikke forfægte repræsentativitet her.

Benn et al. (2015) pointerer, at billeder generelt spiller en større rolle end sproglige tekster ifm. nethandel, men at det, vi kan betegne som den sproglige betydningsskabelse, kommer i spil, når produkterne ligner hinanden, men faktisk er forskellige. Dette harmonerer fint med kunde Bs adfærd, idet hun blandt alle seks kunder i eyetracking-eksperimentet var den, der læste mest om produktet $\mathrm{i}$ sit forsøg på et finde den rigtige poloshirt blandt de mange relativt identiske muligheder.

\section{Konklusion}

I artiklen viser vi, hvorledes nethandel trækker på en række forskellige registre, som den enkelte kunde i større eller mindre grad interagerer med. Nethandel er således kendetegnet ved en sammenfletning af en række teksttyper til en konkret tekst, som kunden selv skaber.

Analysen demonstrerer en fornyet vægt på sproget ved at vise, hvordan mange handlinger, som ikke behøver at blive sprogliggjort i den fysiske verden, bliver sprogliggjort online, fx med menuer, som specificerer forskellige typer af tekstil eller type af skjortekrave, eller med grundige anvisninger på, hvordan man tager mål af sin krop, så man kan vælge den rette størrelse. Når vi betegner vægtningen af sproglig betydningsdannelse som fornyet, skyldes det, at sproget i megen litteratur om multimodalitet har været overset. Siden Kress og van Leeuwen i 1996 udgav Reading Images, har forskningen i multimodalitet helt overvejende fokuseret på alle andre betydningssystemer ("modes") end sproget, mest udbredt på, hvordan fx stillbilleder, levende billeder, grafik, bygninger, musik og påklædning 'betyder' (se fx Riley, 2004; O'Halloran, 2004; Stenglin, 2009; Pang, 
2004; van Leeuwen, 1999; Kress \& van Leeuwen, 1996, 2001; Johannesen, 2016). Et aksiom i denne udforskning af multimodale fænomener har været, at lingvistiske indsigter ikke kan overføres til andre betydningssystemer, men at disse skal kortlægges ud fra egne forudsætninger. Dette bifalder vi, men vi bifalder ikke den konsekvens, som det har haft, nemlig at studiet af sprog overses og måske endda betragtes som forældet i relation til moderne kommunikationsformer. Det er vores opfattelse - og det viser analysen af Zalandos webside også - at sproget skal tages seriøst som ét betydningssystem blandt flere, og at det selvsagt er centralt, når vi studerer kommunikation.

Slutteligt skal det pointeres, at vores studie af Zalandos netbutik indikerer, at nethandel i mindre grad er et multimodalt fænomen, end handel i fysiske butikker er, og at nethandel forudsætter sproglige og visuelle læsefærdigheder, som ikke alle nødvendigvis har. Forskningen i de læsefærdigheder og kompetencer, som er påkrævede for at klare sig i nutidens og fremtidens nethandel, bør efter vores opfattelse sættes højt på dagsordenen.

\section{Referencer}

Aghekyan-Simonian, M., Forsythe, S., Kwon, W.S. \& Chattaraman, V. (2012). The role of product brand image and online store image on perceived risks and online purchase intentions for apparel. Journal of Retailing and Consumer Service, 19, 325-331.

Andersen, T.H. (2007). Sæet ord på! Odense: Syddansk Universitetsforlag

Andersen, T.H. (2013). Registerbegrebet. En teoretisk forankring og et rids over begrebets praktiske anvendelighed til tekstanalyse og tekstforfatning. In S. Hållsten, H.S. Rehnberg \& D. Wojahn (Eds.), Text, kontext och betydelse. Sex nordiska studier i systemisk-funktionell lingvistik (pp. 11-32). Södertörns högskola.

Andersen, T.H. (2015). Situationskontekst - refleksioner og operationalisering. In Kvåle, G., Maagerø, E. \& Veum, A. (Eds.), Kontekst, språk og multimodalitet (pp. 41-59). Bergen: Fagbokforlaget Vigmostad og Bjørke.

Andersen, T.H. \& Holsting, A. (2015). Teksten i grammatikken. Odense: Syddansk Universitetsforlag.

Azar, S., Khan, S.N., \& Shavaid, J. (2015). Familiarity with Online Retailing. The Journal of Developing Areas, 49(6), 133-144.

Baldry, A. \& Thibault, P.J. (2006). Multimodal Transcription and Text Analysis. London: Equinox.

Barnet, B. (2014). Memory Machines. The Evolution of Hyptertext. London and New York: Anthem Press.

Barthes, R. (2013). The Language of Fashion. London and New York: Bloomsbury.

Benn, Y., Webb, T.L., Chang, B.P. \& Reidy, J. (2015). What information do consumers consider, and how do they look for it, when shopping for groceries online? Appetite, 89, 265-273.

Berger, A.A. (2014). Media and Communication Research Methods. An Introduction to Qualitative and Quantitative Approaches. Los Angeles: Sage. $4^{\text {th }}$ ed.

Björkvall, A. (2012). Artefakters betydelsepotentialer: En presentation av den sociosemiotiska etnografin som teori och metod. In Andersen, T.H. \& Boeriis, M. (Eds.), Nordisk socialsemiotik (pp. 59-88). Odense: Odense Universitetsforlag.

Blazquez, M. (2014). Fashion Shopping in Multichannel Retail: The Role of Technology in Enhancing the Customer Experience. International Journal of Electronic Commerce, 18(4), 97-116. 
Bolter, J.D. \& Grusin, R. (2000). Remediation. Understanding New Media. Cambridge MA: The MIT Press. Butt, D. \& Matthiessen, C.M.I.M. (2000). The Meaning Potential of Language: Mapping Meaning Systemically. Sydney: Macquarie University.

Cummins, S., Peltier, J.W., Schibrowsky, J.A. \& Nill, A. (2014). Consumer behavior in the online context. Journal of Research in Interactive Marketing, 8(3), 169-202.

DE (2016). Hvad køber vi mest af på nettet? Danskerhverv.dk. Konsulteret 4. oktober 2017, http://www. danskerhverv.dk/Nyheder/Sider/Hvad-koeber-vi-mest-af-paa-nettet.aspx

Dusto, A. (2012). Many web shoppers solve the try-it-on problem by ordering multiple sizes. Internet Retailer. Konsulteret 4. oktober 2017, https://www.internetretailer.com/2012/10/26/shoppers-solve-tryit-problem-ordering-multiple-sizes.

Endo, S., Yang, J. \& Park, J. (2012). The investigations on dimensions of e-satisfication for online shoes retailing. Journal of Retailing and Consumer Services, 19, 398-405.

Eskjær. M. (2013). The mediatization of ethical consumption. Mediekultur, 54, 26-46.

Fairclough, N. (1992). Discourse and Social Change. Cambridge: Polity Press.

Firth, J.R. (1957). Papers in Linguistics, 1934-1951. London: Oxford University Press.

Firth, J.R. (1968). Selected Papers of J.R. Firth, 1952-59. London: Longman.

Halliday, M.A.K. (1977). Text as semantic choice in social contexts. In Webster, J. (Ed.) (2002), Linguistic Studies of Text and Discourse (pp. 23-81). London: Continuum.

Halliday, M.A.K. (1978). Language as Social Semiotic. London: Arnold.

Halliday, M.A.K. \& Hasan, R. (1976). Cohesion in English. London: Longman.

Halliday, M.A.K. \& Hasan, R. (1985). Language, context and text: Aspects of language in a social-semiotic perspective. Geelong, Vic: Deakin University Press

Halliday, M.A.K. \& Matthiessen, C.M.I.M. (1999). Construing Experience Through Meaning. London: Cassell.

Halliday, M.A.K. \& Matthiessen, C.M.I.M. (2013). Halliday's Introduction to Functional Grammar. $4^{\text {th }}$ edition. London: Routledge.

Heaney, D.B. (2013). 'Don Fabio' and the taming of the three lions: the discursive construction of a foreign England manager's identity in the sports online written media. Mediekultur, 54, 159-180.

Hjarvard, S. (2008). The Mediatization of Society. A Theory of the Media as Agents of Social and Cultural Change. Nordicom Review, 29(2), 105-134.

Hjarvard, S. (2013). The Mediatization of Culture and Society. London: Routledge.

Holmes, J. (1992). An Introduction to Sociolinguistics. London: Longman.

Holsanova, J. \& Holmqvist, K. (2006). Entry points and reading paths on newspaper spreads: comparing a semiotic analysis with eye-tracking measurements. Visual Communication, 5(1), 65-93.

ledema, R. (2001). Resemiotisation, Semiotica, 37 (1/4), 23-40.

ledema, R. (2003). Multimodality, resemiotisation: extending the analysis of discourse as a multi-semiotic practice. Visual Communication, 2(1), 29-58.

Jakobson, R. (1960). Lingvistik og poetik. Vindrosen, 7, 41-52.

Jensen, K.B. (2012). A Handbook of Media and Communication Research. Qualitative and Quantitative Methodologies. London: Routledge.

Johannesen, C.M. (2016). Experiential meaning potential in the Topaz Energy logo: a framework for graphemic and graphetic analysis of graphic logo design. Social Semiotics, 27(1), 1-20.

Johannesen, C.M. \& Boeriis, M. (forthc.). Accelerating semogenesis. An ecosocial approach to photography. Visual Communication.

Kim, J. \& Forsythe, S. (2009). Adoption of sensory enabling technology for online apparel shopping. European Journal of Marketing, 43, 1101-1120. 
Kress, G. (2010). Multimodality: A social semiotic approach to contemporary communication. London: Routledge.

Kress, G. \& Van Leeuwen, T. (1996). Reading Images - The Grammar of Visual Design. London: Routledge.

Kress, G. \& Van Leeuwen, T. (2001). Multimodal Discourse. The Grammar of Visual Design. The Modes and Media of Contemporary Communication. London: Hodder Arnold.

Kvale, S. (1994). InterView. København: Hans Reitzels Forlag.

Lemke, J. (2009). Multimodality, identity, and time. In Jewit, C. (Ed.), The Routledge handbook of multimodal analysis (pp. 140-150). New York \& London: Routledge.

Machin, D. \& Van Leeuwen, T. (2007). Global Media Discourse - A Critical Introduction. London: Routledge.

Martinec, R. \& Van Leeuwen, T. (2009). The language of new media design - theory and practice. London: Routledge.

Melander, R. (2016). Tre ting får kunderne til at flygte - og det er ikke høje priser. Finans.dk. Konsulteret 4. oktober 2017, http://finans.dk/live/erhverv/ECE8908707/tre-ting-faar-kunderne-til-at-flygte-og-deter-ikke-hoeje-priser/

Melsen, S. (2015). Statistikken har talt - kvinder overhaler mænd i nethandel. Trendsonline. Konsulteret 4. oktober 2017, http://trendsonline.dk/2015/02/10/statistikken-har-talt-kvinder-overhaler-maendnethandel/

Moeran, B. (2013). Proposing Fashion: The Discourse of Glossy Magazines. Communicação e Sociedade, 21, 120-142.

O'Halloran, K. (2004). Visual Semiosis in Film. In K. O'Halloran (Ed.), Multimodal Discourse Analysis (pp. 109-130). London: Continuum.

Pang, A.K.M. (2004). Making History in From Colony to Nation: a multimodal analysis of a museum exhibition in Singapore. In K. O'Halloran L. (Ed.). Multimodal Discourse Analysis (pp. 28-54). London: Continuum.

Riley, H. (2004). Perceptual modes, semiotic codes, social mores: a contribution towards a social semiotics of drawing. Visual Communication, 3(3), 294-315.

Rocamora, A. (2016). Mediatization and Digital Media in the Field of Fashion. Fashion Theory. Konsulteret via: http://www.tandfonline.com/doi/full/10.1080/1362704X.2016.1173349.

Saldanha, G. \& O'Brien, S. (2013). Research Methodologies in Translation Studies. London: Routledge.

Sandvik, K. (2009). Researching online worlds: Challenging media and communication studies. Mediekultur, 47(25); special issue.

Schramm-Klein, H., Swoboda, B. \& Morschett, D., (2007). Internet vs brick-and-mortar stores - Analyzing the influence of shopping motives on retail channel choice among internet users. Journal of Customer Behaviour, 6(1), 19-36.

Schultz. W. (2004). Recunstructing Mediatization as an Analytical Concept. European Journal of Communication, 19(1), 87-101.

Stenglin, Mt.K. (2009). Space odyssey: towards a social semiotic model of three-dimensional space. Visual Communication, 8, 35-64.

Taylor, C. (2017). Reading images (including moving ones). In Bartlett, T. \& O'Grady, G. (Eds.), The Routledge handbook of systemic functional linguistics (pp. 575-590). New York \& London: Routledge.

Van Leeuwen, T. (1999). Speech, Music, Sound. London: Palgrave Macmillan.

Van Leeuwen, T. (2008). Discourse and Practice: New Tool for Critical Analysis. Oxford: Oxford University Press.

Westera, W. (2013). On the cybernetic arrangement of feedback in serious games: a systems-theoretical perspective. Education and Information Technologies, 20(1), 57-73.

Wodak, R. (2015). The Politics of Fear. London: Sage 
Article: Hvorfor og hvordan 'betyder' nethandel?

Zappavigna, M. \& Zhao, S. (2017). Beyond the self: Intersubjectivity and the social semiotic interpretation of the selfie. New Media \& Society. Konsulteret via: http://journals.sagepub.com/doi/

full/10.1177/1461444817706074

Thomas Hestbcek Andersen

Associate Professor, PhD.

University of Southern Denmark

thandersen@sdu.dk

Theo van Leeuwen

Professor in Multimodality

University of Southern Denmark

leeuwen@sdu.dk 